\title{
Combination Treatment of Sorafenib and Bufalin Induces Apoptosis in NCI-H292 Human Lung Cancer Cells In Vitro
}

\author{
JUNG-YU KUO ${ }^{1}$, CHING-LUNG LIAO ${ }^{2}$, YI-SHIH MA ${ }^{3,4}$, CHAO-LIN KUO ${ }^{5}$, JAW-CHYUN CHEN ${ }^{6}$, \\ YI-PING HUANG ${ }^{7}$, WEN-WEN HUANG ${ }^{1}$, SHU-FEN PENG ${ }^{1,8^{*}}$ and JING-GUNG CHUNG ${ }^{1 *}$ \\ ${ }^{1}$ Department of Biological Science and Technology, China Medical University, Taichung, Taiwan, R.O.C.; \\ ${ }^{2}$ College of Chinese Medicine, School of Post-Baccalaureate Chinese Medicine, \\ China Medical University, Taichung, Taiwan, R.O.C.; \\ ${ }^{3}$ School of Chinese Medicine for Post-Baccalaureate, I-Shou University, Kaohsiung, Taiwan, R.O.C.; \\ ${ }^{4}$ Department of Chinese Medicine, E-Da Hospital, Kaohsiung, Taiwan, R.O.C.; \\ ${ }^{5}$ Department of Chinese Pharmaceutical Sciences and Chinese Medicine Resources, \\ China Medical University, Taichung, Taiwan, R.O.C.; \\ ${ }^{6}$ Department of Medicinal Botanicals and Health Applications, \\ Da-Yeh University, Changhua, Taiwan, R.O.C.; \\ ${ }^{7}$ Department of Physiology, School of Medicine, China Medical University, Taichung, Taiwan, R.O.C.; \\ ${ }^{8}$ Department of Medical Research, China Medical University Hospital, Taichung, Taiwan, R.O.C.
}

\begin{abstract}
Background/Aim: Lung cancer notably contributes to tumor-associated mortality worldwide, and standard chemotherapy is used for lung cancer patients. However, its therapeutic efficacy remains unsatisfactory. This study aimed to evaluate the effects and molecular mechanisms of sorafenib and bufalin combination therapy on lung cancer cells in vitro. Materials and Methods: NCI-H292 cells were treated with sorafenib, bufalin, and sorafenib in combination with bufalin. Cell viability, ROS production, $\mathrm{Ca}^{2+}$ release, and mitochondrial membrane potential were examined by flow cytometric assay. Annexin V/PI staining and chromatin condensation were examined by the apoptosis assays. Finally the molecular mechanism of apoptosis-associated protein expression was investigated by western blotting. Results: $\mathrm{NCI}$ -
\end{abstract}

This article is freely accessible online.

*These Authors contributed equally to this study.

Correspondence to: Shu-Fen Peng, Ph.D., Department of Medical Research, China Medical University Hospital, No. 2, Yude Road, Taichung 404, Taiwan, R.O.C. Tel: +886 422053366 ext. 2527, Fax: +886 422071507, e-mail: t20811@mail.cmuh.org.tw; Jing-Gung Chung, Ph.D., Department of Biological Science and Technology, China Medical University, No. 100, Sec. 1, Jingmao Road, Taichung 406, Taiwan, R.O.C. Tel: +886422053366 ext. 2531, Fax: +886 4-22071507, e-mail: jgchung@mail.cmu.edu.tw

Key Words: Sorafenib, bufalin, combination therapy, lung cancer, apoptosis.
H292 cells treated with sorafenib in combination with bufalin showed significantly decreased viability, enhanced cellular apoptosis, and DNA condensation when compared to that with sorafenib or bufalin alone. Moreover, the combination treatment exhibited higher reactive oxygen species (ROS) production and lower mitochondrial membrane potential $(\Delta \Psi \mathrm{m})$. The combined treatment resulted in higher expression of SOD but lower catalase compared to sorafenib treatment alone. Compared to sorafenib or bufalin treatment alone, the combination treatment resulted in lower Bcl-2 expression but higher Bax, Bad, APAF-1, caspase-3, and caspase-9. Conclusion: Sorafenib in combination with bufalin shows more potent cytotoxic effects and cell apoptosis than sorafenib or bufalin treatment alone in NCI-H292 cells. The combined treatment significantly enhanced apoptotic cell death in NCIH292 lung cancer cells by activating ROS-, mitochondria-, and caspase-signaling pathways in vitro.

Cancer affects human health globally with its incidence being the most severe public issue of the $21^{\text {st }}$ century. The global number of lung cancer deaths remains high yearly (1). Lung cancers are mainly divided into two subtypes, including nonsmall cell lung cancer (NSCLC) and small cell lung cancer (SCLC). However, the NSCLC subtype occupies about 80$85 \%$ of lung cancers (2). Currently, patients undergo surgery, radiation, chemotherapy, and targeted therapy as the most commonly used strategies for lung cancer. Yet clinical outcomes of current therapies remain unsatisfactory: the 5year survival rate of lung cancer patients is less than $15 \%$ (3), and that of patients with metastatic disease is less than $10 \%$ 
(4). Thus, identifying novel anti-cancer drugs to minimize the side-effects or improving the effectiveness of treatments is considered a matter of urgent importance (5).

Sorafenib, a multi-kinase inhibitor for treating advanced liver cancer, is generally well-tolerated with promising efficacy in various malignancies, including lung cancer. Furthermore, it has been shown to be functional against various tumors in preclinical models (6) and has also been presented to exert anticancer activity in patients with relapsed NSCLC (7). In particular, ARAF mutation is an oncogenic factor that drives lung adenocarcinoma and is also used as an indicator for sorafenib response (8). In vitro studies have shown that sorafenib inhibited epithelial-to-mesenchymal transition (EMT) mediated by transforming growth factor- $\beta 1$ in A549 human lung cancer cells (9). However, the development of drug resistance after sorafenib treatment resulted in limited survival benefit with meager response rates (10). Many studies have reported the antitumor effect of sorafenib in preclinical NSCLC models $(11,12)$. Nevertheless, sorafenib treatment is also accompanied by side-effects such as adverse hand-foot skin diseases, hypertension, and diarrhea (13), which result in implementation of low doses, thereby affecting efficacy.

Recently, natural products and their derivatives have shown striking potential for modern drug discovery and development (14). Bufalin, a class of steroids, is purified from the parotid glands and skin of a Chinese toad popularly known as Chansu (Bufo gargarizans) and is used in Chinese traditional medicine $(15,16)$. Bufalin showed antitumor activities in many human cancer cells such as leukemia cells (17), T24 bladder cancer cells (18), MGC803 gastric cancer cells (19), DU145 and PC3 prostate cancer cells (20), glioma cancer cells (21), breast cancer (22), and liver cancer (23). Our previous findings have shown that bufalin caused apoptotic cell death in human nasopharyngeal carcinoma cells (24) and against lung cancer xenograft animals in vivo (25). Furthermore, we also found that bufalin promoted phagocytosis of macrophages in peripheral blood and the peritoneal cavity in leukemia mice in vivo (26).

Due to the adverse side-effects of sorafenib treatment, new therapeutic strategies have focused on combining sorafenib with natural drugs for improving the critical defects of sorafenib treatment. Therefore, the present study investigated the effects of sorafenib combined with bufalin on inducing cell apoptosis in NCI-H292 human lung cancer cells. We found that combination treatment demonstrates a synergistic effect on inducing cell death and causing cell apoptosis via intrinsic pathways in NCI-H292 cells.

\section{Material and Methods}

Chemicals and reagents. Sorafenib, bufalin, 4,6-diamidino-2phenylindole (DAPI), propidium iodide (PI), trypsin-EDTA, the reagents for the detection of $\mathrm{ROS}, \mathrm{Ca}^{2+}$, mitochondrial membrane potential $(\Delta \Psi m)$, and RIPA buffer were brought from SigmaAldrich Corp. (St. Louis, MO, USA). RPMI-1640 medium, fetal bovine serum (FBS), penicillin, streptomycin, and L-glutamine were brought from Invitrogen Life Technologies (Carlsbad, CA, USA). PVDF membranes were brought from Merck Millipore (Billerica, MA, USA). Primary antibodies against ROS stress- and apoptosisassociated proteins were purchased from Santa Cruz Biotechnology Inc. (Santa Cruz, CA, USA) and Cell Signaling Technology (Irvine, CA, USA). Secondary antibodies (goat anti-rabbit or mouse IgG) were received from Amersham Pharmacia Biotech, Inc (Piscataway, NJ, USA).

Cell culture. The NCI-H292 human lung cancer cells (non-small cell lung cancer cells) were brought from Food Industry Research and Development Institute (Hsinchu, Taiwan, ROC). Cells were maintained in RPMI-1640 medium containing 10\% FBS, 2 mM Lglutamine, and $1 \%$ antibiotics $(100 \mu \mathrm{g} / \mathrm{ml}$ streptomycin and 100 units $/ \mathrm{ml}$ penicillin) under a humidified atmosphere of $5 \% \mathrm{CO}_{2}$ at $37^{\circ} \mathrm{C}$ according to the guidelines from the provider (27).

Cell viability and morphology. NCI-H292 cells at a density of $1 \times 10^{5}$ cells per well were seeded in 12-well plates overnight. Cells were subjected to sorafenib $(0,10,15$, and $20 \mu \mathrm{M})$, bufalin $(0,60,90$, and $120 \mathrm{nM})$, or sorafenib $(0,10,15$, and $20 \mu \mathrm{M})$ combined with bufalin $(0,60,90$, and $120 \mathrm{nM})$ for $48 \mathrm{~h}$. Before the cells being processed, the cell morphology was observed and imaged under a phase-contrast microscope.

After treatment, NCI-H292 cells were individually collected for cell viability detection. The cell pellets were resuspended in PI solution $(5 \mu \mathrm{g} / \mathrm{ml})$ and measured by flow cytometry. In addition, the effects of combination treatment on cell viability were evaluated for calculating the coefficient of drug interaction (CDI) value as cited previously (28).

Determination of cell apoptotic cell death. NCI-H292 $\left(1 \times 10^{5}\right.$ cells per well) were added in 12 -well plates. Following indicated drug treatments $(15 \mu \mathrm{M}$ sorafenib, $90 \mathrm{nM}$ bufalin, or the combination of $15 \mu \mathrm{M}$ sorafenib with $90 \mathrm{nM}$ bufalin) for $48 \mathrm{~h}$, cells were isolated and harvested. Cells were determined the apoptotic cell death by staining with FITC-conjugated Annexin V/PI solution for $15 \mathrm{~min}$ in the dark. After incubation, cells were measured the apoptotic cell number by flow cytometric assays described previously (27).

Chromatin condensation assay. NCI-H292 cells were seeded in 12well plates at a density of $1 \times 10^{5}$ cells/well and incubated with 15 $\mu \mathrm{M}$ sorafenib, $90 \mathrm{nM}$ bufalin, or a combination of $15 \mu \mathrm{M}$ sorafenib with $90 \mathrm{nM}$ bufalin for $48 \mathrm{~h}$. After treatment, cells in each well were fixed with a freshly prepared $4 \%$ paraformaldehyde (in PBS) for 15 min and permeabilized their cell membranes by $0.1 \%$ Triton X-100 for $5 \mathrm{~min}$. DAPI solution $(2 \mu \mathrm{g} / \mathrm{ml})$ was then incubated with the cells for $10 \mathrm{~min}$, and the nuclear morphology of the cells was observed and photographed with a fluorescence microscope at $100 \times$ as described previously (27).

Determination of reactive oxygen species and intracellular $\mathrm{Ca}^{2+}$ production and mitochondrial membrane potential $\left(\Delta \Psi_{m}\right)$ levels. NCI-H292 cells $\left(1 \times 10^{5}\right.$ cells/well) were added in 12-well plates and treated with $15 \mu \mathrm{M}$ sorafenib, $90 \mathrm{nM}$ bufalin, or the combination of $15 \mu \mathrm{M}$ sorafenib with $90 \mathrm{nM}$ bufalin for $48 \mathrm{~h}$. After treatment, cells were collected and resuspended in $500 \mu \mathrm{l}$ of DCFH-DA $(10 \mu \mathrm{M})$ for 
evaluating the changes in the levels of reactive oxygen species (ROS $\mathrm{H}_{2} \mathrm{O}_{2}$ content). For determining intracellular $\mathrm{Ca}^{2+}$ levels or analyzing the changes of $\Delta \Psi_{m}$, cells were harvested and resuspended in $500 \mu \mathrm{l}$ of Fluo-3/AM $(2.5 \mu \mathrm{g} / \mathrm{ml})$ or $\mathrm{DiOC}_{6}(4 \mu \mathrm{mol} / \mathrm{ml})$, respectively, and measured by flow cytometry as cited previously (27).

Western blotting analysis. NCI-H292 $\left(1 \times 10^{6}\right.$ cells $)$ cells were seeded in 10-cm dishes and incubated with $15 \mu \mathrm{M}$ sorafenib, $90 \mathrm{nM}$ bufalin, or the combination treatment $(15 \mu \mathrm{M}$ sorafenib and $90 \mathrm{nM}$ bufalin) for $48 \mathrm{~h}$. After exposure to different treatments, cells were gathered, and cell lysates were obtained by adding ice-cold RIPA buffer containing protease inhibitor (SigmaFAST Protease Inhibitor Cocktail; Sigma-Aldrich). The Bradford reagent (Bio-Rad protein assay kit; Hercules, CA, USA) was used to calculate the protein concentrations (27). A certain amount of total protein $(30 \mu \mathrm{g})$ was electrophoresed on $8-12 \%$ of SDS-polyacrylamide gel and subsequently transferred onto PVDF membranes. The resultant membrane was blocked with $2 \% \mathrm{BSA}$ for $1 \mathrm{~h}$ at room temperature. Subsequently, the membranes were incubated with specific primary antibodies at $4^{\circ} \mathrm{C}$ overnight. After treatment with corresponding horseradish peroxidase-conjugated secondary antibodies for $2 \mathrm{~h}$ at room temperature, protein bands were visualized using the Enhanced Chemiluminescence kit (NEN Life Science Products, Inc, Boston, MA, USA) as described previously (27). The intensity of protein bands was determined and quantified using NIH-ImageJ version 1.47 .

Statistical analysis. All experiments were performed three times, and data were presented as the mean \pm SD. One-way ANOVA analysis was analyzed to compare two experimental groups. For all tests, a $p$-value $<0.05$ was considered to be statistically significant.

\section{Results}

Sorafenib, bufalin, or sorafenib in combination with bufalin affected cell viability and morphology of NCI-H292 cells. NCI-H292 cells were incubated with different concentrations of sorafenib $(0,10,15$, and $20 \mu \mathrm{M})$ or bufalin $(0,60,90$, and $120 \mathrm{nM}$ ) for $48 \mathrm{~h}$. For cell viability, cells were collected and determined the PI exclusion by flow cytometry. Results revealed that treatment with $20 \mu \mathrm{M}$ sorafenib or $60-120 \mathrm{nM}$ bufalin significantly decreased the total viable cell number by $33 \%$, or around $12-24 \%$, respectively (Figure $1 \mathrm{~A}$ and B).

To further determine the effects of combination treatment on cell viability, the cells were incubated with the combination of sorafenib (10-20 $\mu \mathrm{M})$ and bufalin (60-120 $\mathrm{nM}$ ) for $48 \mathrm{~h}$, and cell viability was examined. Results revealed that the treatment of sorafenib in combination with bufalin significantly decreased the viability of NCI-H292 cells compared to that of sorafenib or bufalin treatment alone (Figure 1C). Furthermore, after calculating the coefficient of drug interaction (CDI) value, optimal effects on cell viability were displayed in the combination of sorafenib at $15 \mu \mathrm{M}$ and bufalin at $90 \mathrm{nM}$ due to the lower concentration of sorafenib and optimal CDI value of 0.67 (Table I). Thus, the drug combination at $15 \mu \mathrm{M}$ sorafenib and $90 \mathrm{nM}$ bufalin was applied for further experiments.
After treatment, cell morphology was examined and snaped under phase-contrast microscopy. Results revealed that cells subjected to the two-drug combination $(15 \mu \mathrm{M}$ of sorafenib and $90 \mathrm{nM}$ of bufalin) exhibited more significant morphological changes than those treated with sorafenib or bufalin alone (Figure 1D). These observations were also consistent with the results of the total cell viability.

Sorafenib, bufalin, or sorafenib in combination with bufalin affected the apoptosis in NCI-H292 cells. For measuring the apoptotic effects of sorafenib, bufalin, or the combination of sorafenib with bufalin on NCI-H292 cells, cells were stained with Annexin V and PI and assayed by flow cytometry. Firstly, cells were incubated with $15 \mu \mathrm{M}$ sorafenib, $90 \mathrm{nM}$ bufalin, or $15 \mu \mathrm{M}$ sorafenib in combination with $90 \mathrm{nM}$ bufalin for $48 \mathrm{~h}$. Subsequently, cells were probed with Annexin V and stained with the PI solution to measure cell death, including earlier or later apoptotic cell death, using flow cytometric assay. Results revealed that treatment of NCI-H292 cells with the two-drug combination for $48 \mathrm{~h}$ led to a higher percentage of apoptotic cells than that of sorafenib or bufalin treatment alone (Figure 2A and B). These observations indicated that the two-drug combination showed an enhanced effect on NCI-H292 cells, consistent with the results of cell viability assays.

Sorafenib, bufalin, or sorafenib in combination with bufalin affected DNA condensation in NCI-H292 cells. In order to assess the effect of individual and combination drug treatment on the nuclear morphology, DAPI staining was performed. NCI-H292 cells were incubated with $15 \mu \mathrm{M}$ sorafenib, $90 \mathrm{nM}$ bufalin, or drug combination for $48 \mathrm{~h}$. Then cells were stained with DAPI solution, examined, and photographed (Figure 3A and B). Compared to single-drug treatment (sorafenib or bufalin alone), the two-drug combination treatment results in significant DNA condensation in NCI-H292 cells, as demonstrated by higher fluorescence intensity in the nucleus of the cells (Figure 3A). Calculation of fluorescence intensity further clearly revealed that the two-drug combination treatment presented higher DNA condensation in NCI-H292 cells than sorafenib or bufalin treatment alone (Figure 3B).

Sorafenib, bufalin, or sorafenib in combination with bufalin affected the production of reactive oxygen species, $\mathrm{Ca}^{2+}$ release, and the levels of mitochondrial membrane potential in NCI-H292 cells. Oxidative and ER stresses and mitochondria membrane potential (MMP; $\Delta \Psi m$ ) are involved in various cell apoptosis aspects. For determining the specific mechanism underlying cellular apoptosis, we monitored the changes of ROS, $\mathrm{Ca}^{2+}$, and MMP. NCI-H292 cells were treated with $15 \mu \mathrm{M}$ sorafenib, $90 \mathrm{nM}$ bufalin, or their combination for $48 \mathrm{~h}$. Then their ROS production, $\mathrm{Ca}^{2+}$ 

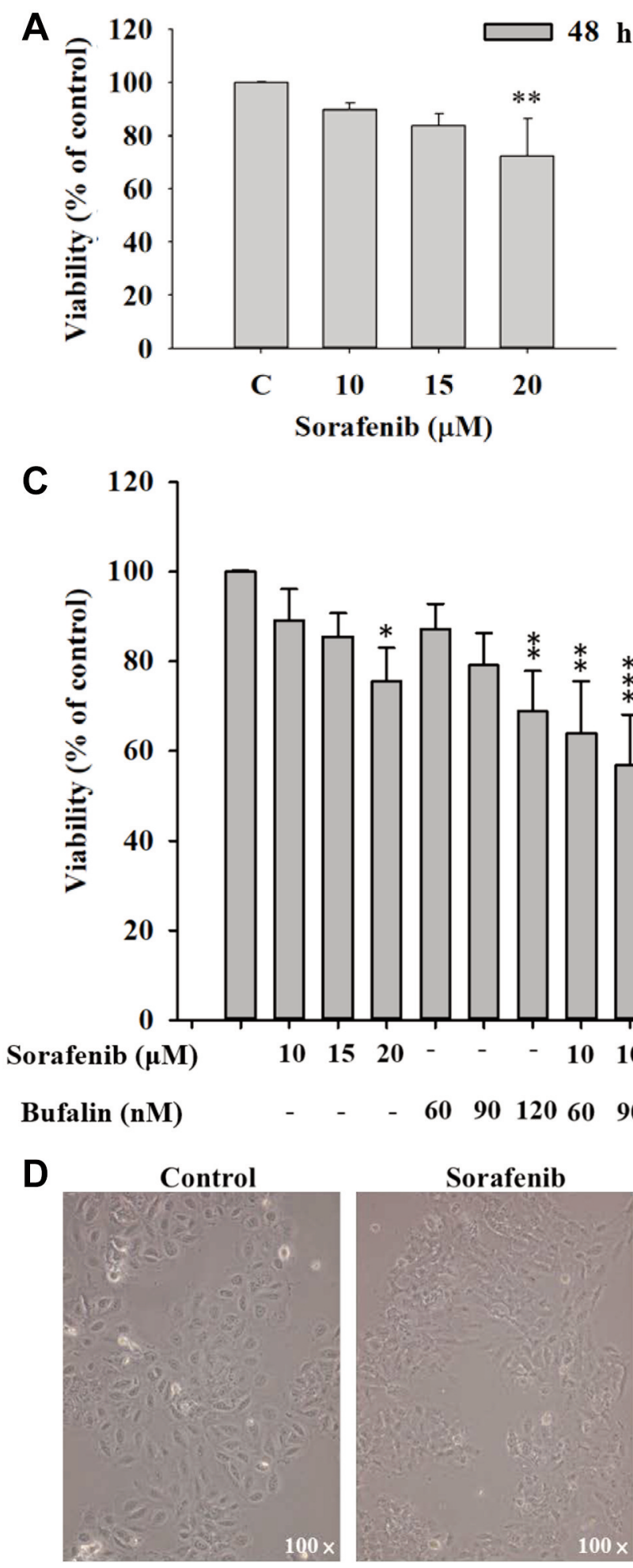

B

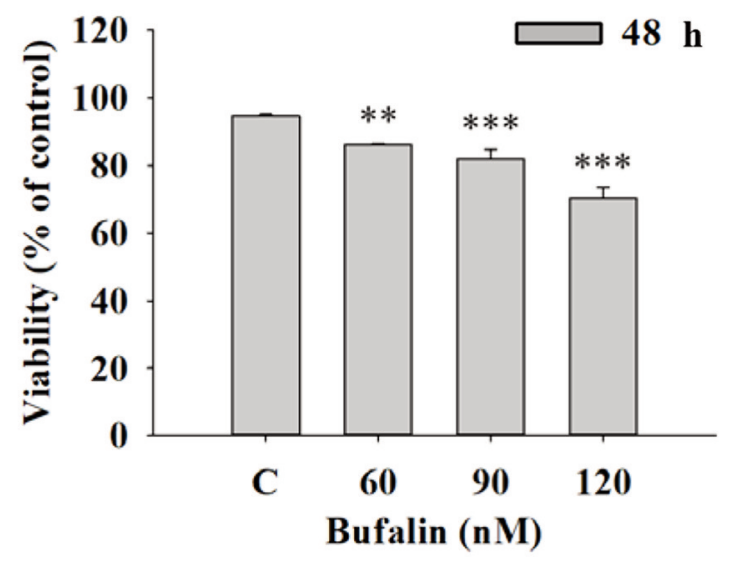

$48 \mathrm{~h}$ 
Table I. Synergistic effects of sorafenib and bufalin in NCI-H292 human lung cancer cells.

\begin{tabular}{lccc}
\hline Sorafenib $(\mu \mathrm{M})$ & Bufalin $(\mathrm{nM})$ & Cell viability $(\%)$ & CDI \\
\hline- & - & 100.00 & - \\
10 & - & 89.18 & - \\
15 & - & 85.54 & - \\
20 & - & 75.50 & - \\
- & 60 & 87.22 & - \\
- & 90 & 79.13 & - \\
- & 120 & 77.89 & - \\
10 & 60 & 63.95 & 0.82 \\
10 & 90 & 56.83 & 0.81 \\
10 & 120 & 60.53 & 0.87 \\
15 & 60 & 57.31 & 0.77 \\
15 & 90 & 45.29 & 0.67 \\
15 & 120 & 47.23 & 0.71 \\
20 & 60 & 42.52 & 0.65 \\
20 & 90 & 39.56 & 0.66 \\
20 & 120 & 39.01 & 0.66 \\
\hline
\end{tabular}

CDI: Coefficient of drug interaction.

release, and the changes of $\Delta \Psi m$ levels were examined by flow cytometric assays (Figure 4). Data revealed that the combination of sorafenib and bufalin treatment resulted in a higher ROS production (Figure $4 \mathrm{~A}$ and $\mathrm{B}$ ), $\mathrm{Ca}^{2+}$ release (Figure $4 \mathrm{C}$ and $\mathrm{D}$ ), and $\Delta \Psi m$ (Figure $4 \mathrm{E}$ and $\mathrm{F}$ ) compared to treatment of bufalin alone at $48 \mathrm{~h}$. Nevertheless, sorafenib and bufalin combination treatment caused a lower level of ROS production (Figure $4 \mathrm{~A}$ and $\mathrm{B}$ ), $\mathrm{Ca}^{2+}$ release (Figure $4 \mathrm{C}$ and $\mathrm{D}$ ), and $\Delta \Psi_{m}$ (Figure $4 \mathrm{E}$ and $\mathrm{F}$ ) compared to treatment of sorafenib alone at $48 \mathrm{~h}$. However, combination treatment increased ROS production but decreased the $\Delta \Psi m$, and did not alter the $\mathrm{Ca}^{2+}$ release at $48 \mathrm{~h}$.

Sorafenib, bufalin, or a combination of sorafenib and bufalin affected the expression of ROS- or apoptosis-associated proteins in NCI-H292 cells. In order to further substantiate the findings of cell viability and apoptosis assays, we investigated the ROS- or apoptosis-associated protein expression in NCI-H292 cells after treating cells with sorafenib, bufalin, or their combination. Immunoblotting studies from cell lysates after various treatments showed that the two-drug combination treatment significantly elevated the SOD expression, including SOD $(\mathrm{Mn})$ and SOD $(\mathrm{Cu} / \mathrm{Zn})$, but reduced the level of catalase compared to single-drug treatment alone (Figure 5A). The combined drug treatment showed diminished expression of Bcl-2 (anti-apoptotic protein); whereas, the same treatment elevated the expression of pro-apoptotic proteins including Bax, Bak, and Bad compared to sorafenib or bufalin treatment alone (Figure 5B). The combination treatment also significantly elevated the expression of APAF-1 compared to treatment with sorafenib or bufalin alone (Figure 5C). Moreover, the two-drug combination treatment also elevated the expression of the active form of caspase-3 and -9 in NCI-H292 cells compared to sorafenib or bufalin treatment alone (Figure 5D).

\section{Discussion}

Lung cancer is the most prevalent cancer globally. Unfortunately, patients diagnosed at median or advanced stages of lung cancer lead to treatment failure and a low cure rate. Moreover, patients subjected to chemotherapy often develop drug resistance $(2,29)$ and are accompanied by sideeffects making their recovery further challenging. Hence, identifying natural compounds for treating lung cancer has garnered the attention of researchers (14). In the present study, we investigated the effects and molecular mechanism of a two-drug combination (sorafenib combined with bufalin) on apoptosis in human lung cancer cells (NCI-H292 cells) in vitro. The rationale underlying the selection of sorafenib for this study is that sorafenib is the standard first-line therapy for patients with advanced hepatocellular carcinoma (10). However, in phase III studies, the usage of sorafenib combined with other chemotherapy drugs showed the failure of a significant survival benefit in treating NSCLC patients (30). Besides, the precise molecular mechanisms of sorafenib remain unclear (31). Bufalin, a traditional medicine amongst the Chinese population, has been shown to inhibit cell proliferation and cause apoptotic cell death in various human cancer cell lines $(19,32-35)$. However, the efficacy and molecular mechanisms of the two-drug combination (bufalin combined with sorafenib) on inducing apoptosis in NCIH292 lung cancer cells have not been explored.

In the present study, sorafenib at $20 \mu \mathrm{M}$ significantly decreased the cell viability of NCI-H292 cells by $28 \%$ (Figure 1A), while bufalin at $60-120 \mathrm{nM}$ decreased the cell viability from 14 to $29 \%$, respectively (Figure 1B). The combination of sorafenib and bufalin further significantly reduced the total number of viable cells compared to sorafenib or bufalin treatment alone (Figure 1C). The combination index (coefficient of drug interaction; CDI) values of both drug combinations affecting the total cell viability are presented in Table I. It shows that the combination of $15 \mu \mathrm{M}$ sorafenib and $90 \mathrm{nM}$ bufalin has the lower sorafenib concentration and acceptable CDI value of 0.67. Hence, this drug combination concentration was used for further experiments. Assessment of cellular morphology showed that treatment with the drug combination $(15 \mu \mathrm{M}$ sorafenib and $90 \mathrm{nM}$ bufalin) causes more significant morphological changes than that with sorafenib or bufalin treatment alone (Figure 1D). These changes are also consistent with the results of total cell viability. Sorafenib has been previously used in combination with another clinical anti-cancer drug, betulinic acid, to treat NSCLC cells 
A
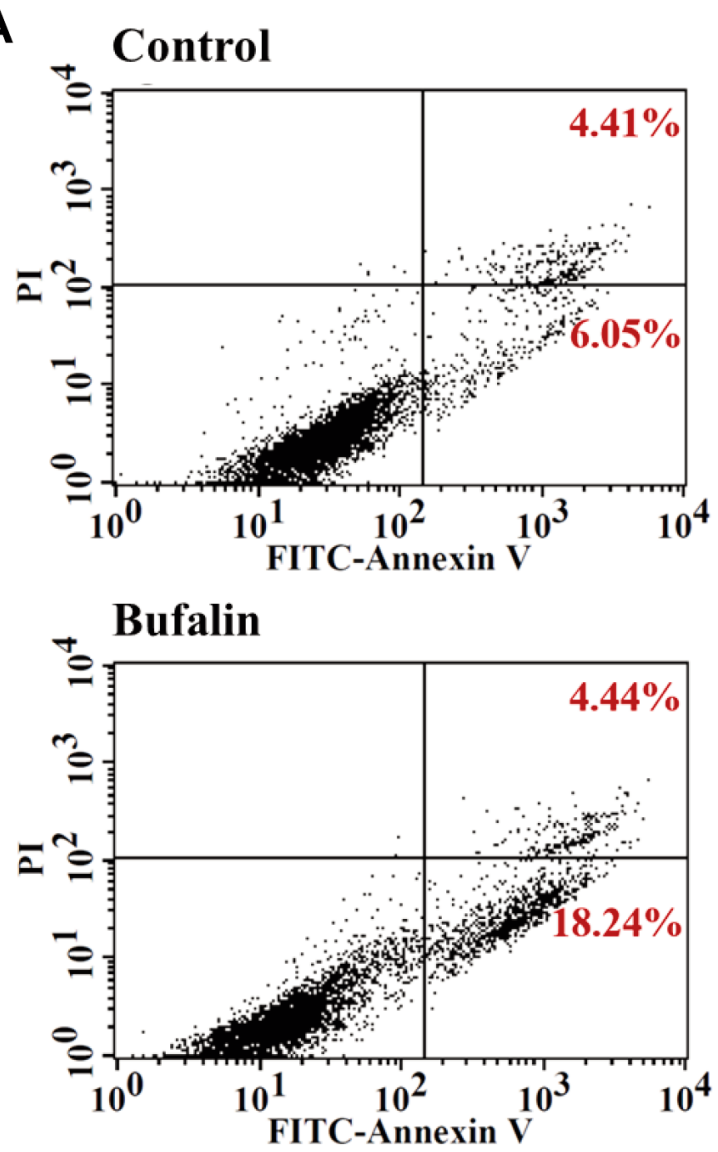
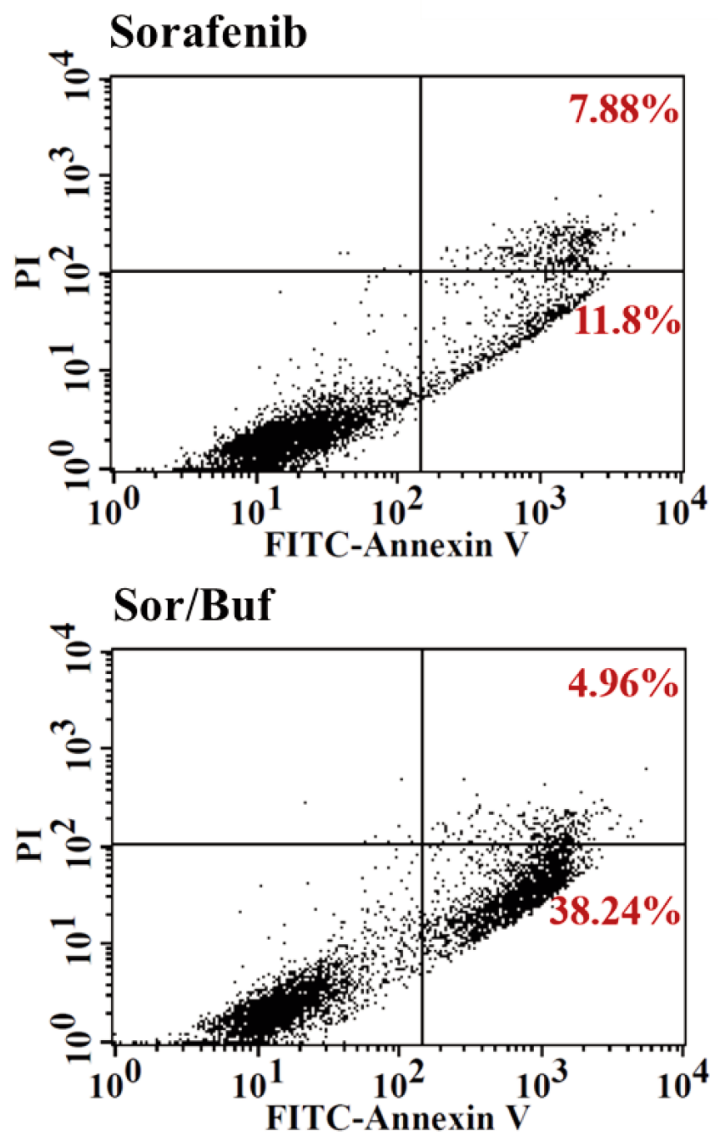

B

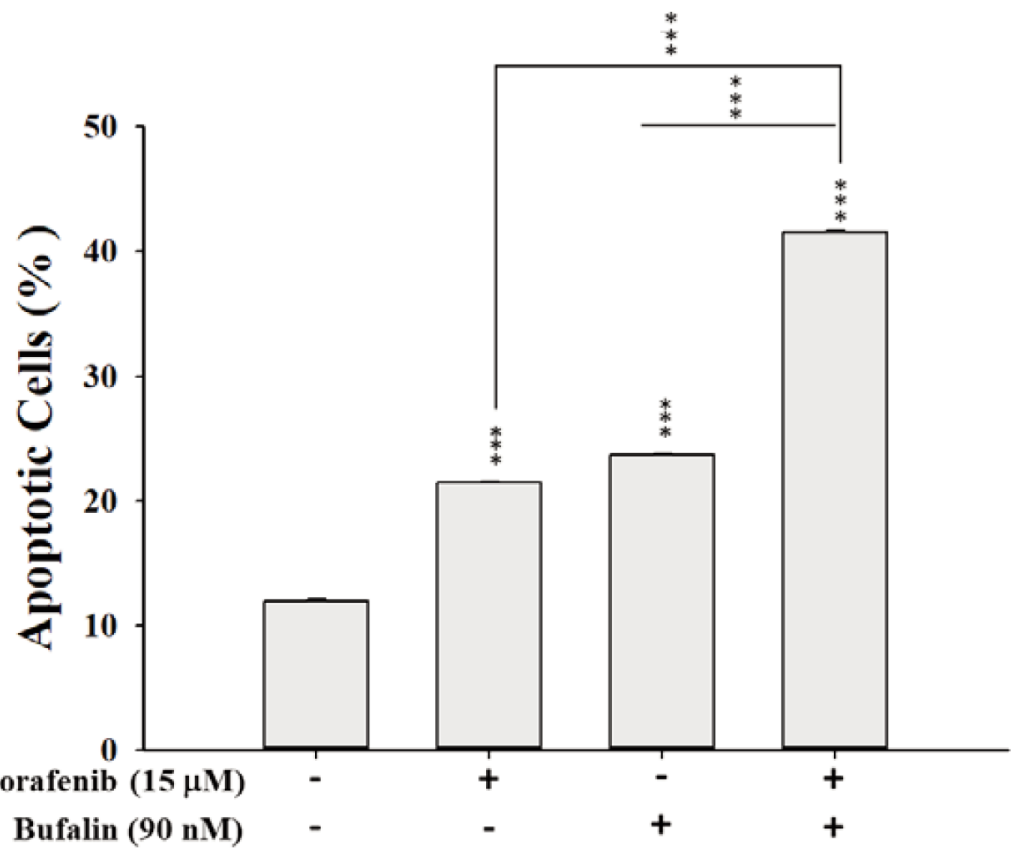

Figure 2. Sorafenib, bufalin, or their combination treatment affected cell apoptosis in NCI-H292 cells. Cells ( $1 \times 10^{5}$ cells/well) were subjected to $15 \mu \mathrm{M}$ sorafenib, $90 \mathrm{nM}$ bufalin, or combination of $15 \mu \mathrm{M}$ sorafenib with $90 \mathrm{nM}$ bufalin for $48 \mathrm{~h}$. Cells were treated with Annexin V/PI solution to determine the percentage of apoptosis, including earlier and late apoptotic cell death, by flow cytometric assays (A). The percentage of cell apoptosis was calculated $(B)$. Data represent mean $\pm S D .{ }^{*} p<0.05$, ** $p<0.01$, or ${ }^{* * *} p<0.001$, a statistically significant difference between the two groups. 


\section{A Control}

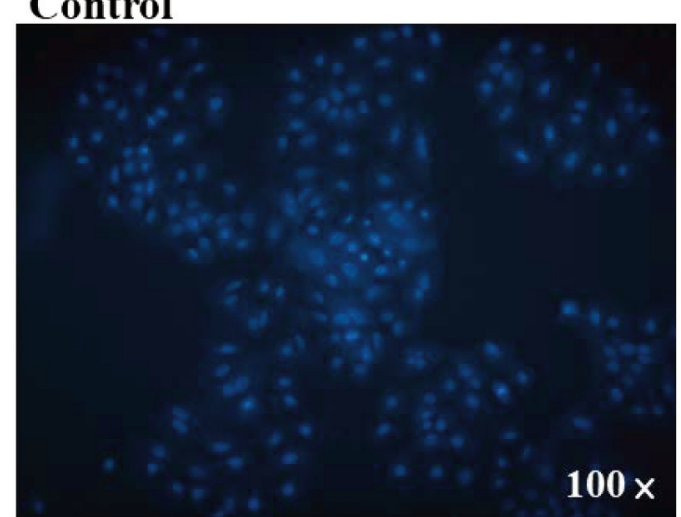

Sorafenib

\section{Bufalin}

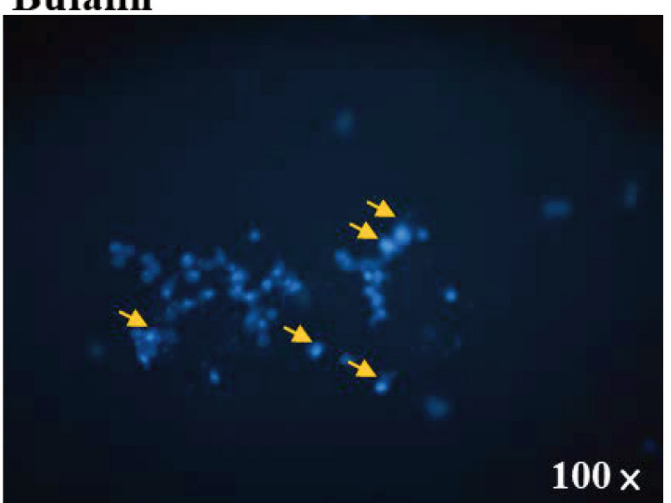

Sor/Buf

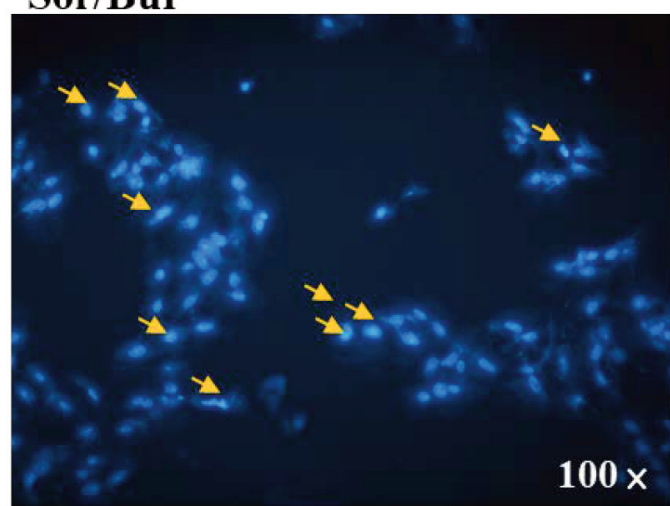

B

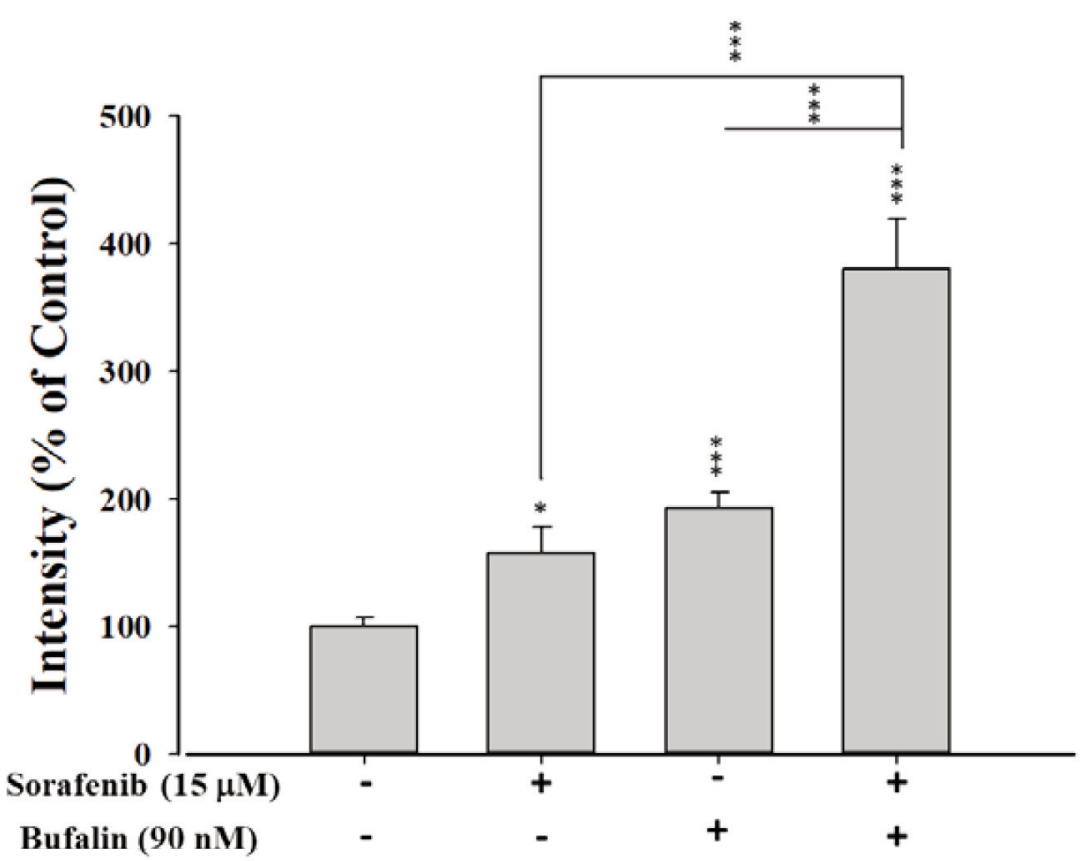

Figure 3. Sorafenib, bufalin, or sorafenib combined with bufalin affected DNA condensation in NCI-H292 cells. Cells $\left(1 \times 10^{5}\right.$ cells/well $)$ were subjected to $15 \mu \mathrm{M}$ sorafenib, $90 \mathrm{nM}$ bufalin, or the combination of $15 \mu \mathrm{M}$ sorafenib with $90 \mathrm{nM}$ bufalin for $48 \mathrm{~h}$. After treatment, cells were stained with DAPI solution and then observed and photographed under a fluorescence microscope at 100x (A). The relative intensity of DAPI fluorescence in the nucleus was calculated $(B)$. Data represent mean $\pm S D$. * $p<0.05$, ** $p<0.01$, or $* * * p<0.001$, a statistically significant difference between the two groups. 
A

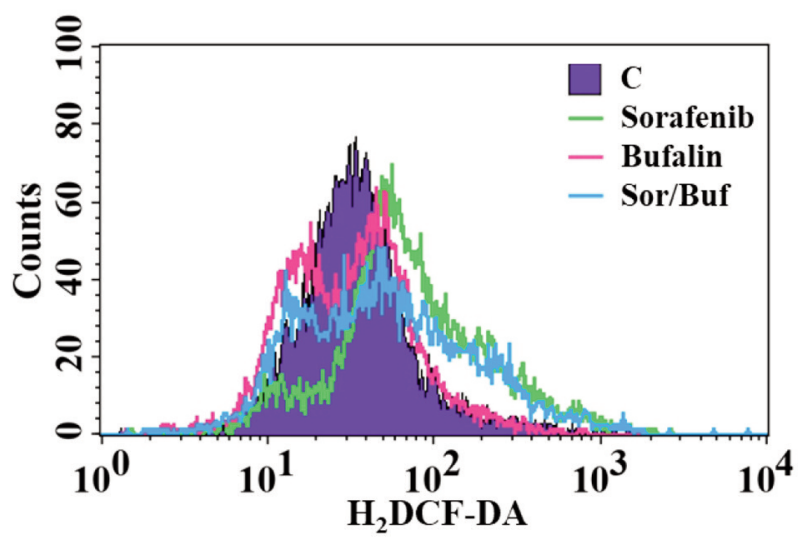

C

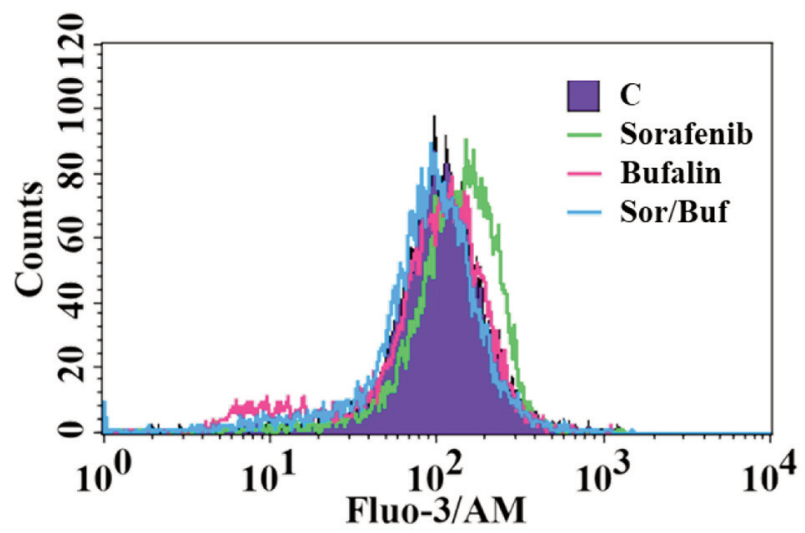

$\mathbf{E}$

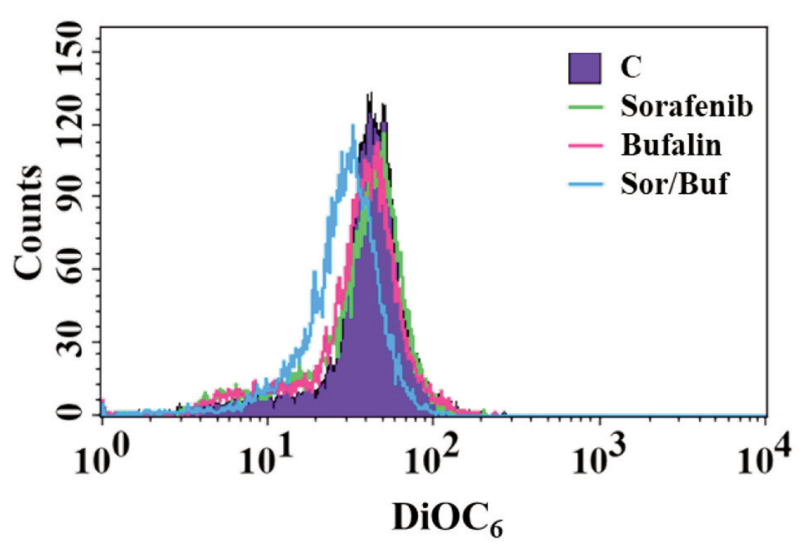

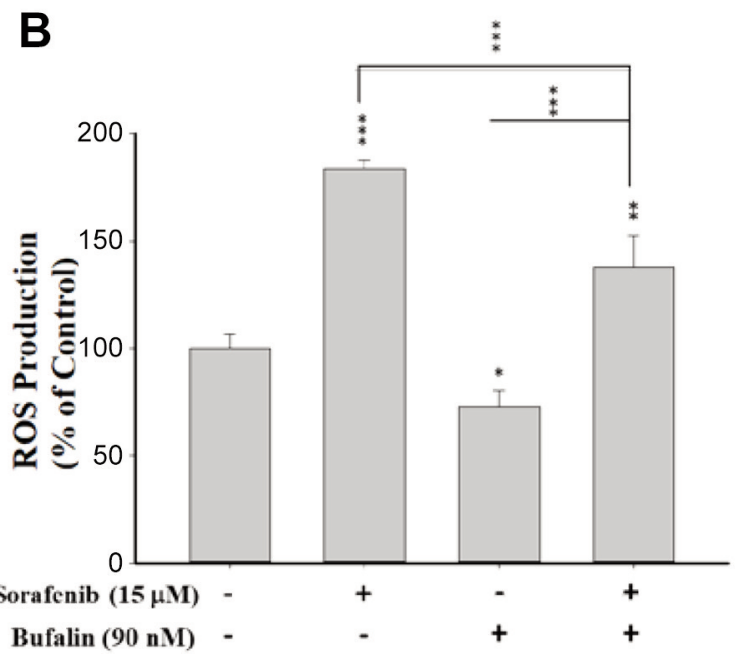

D

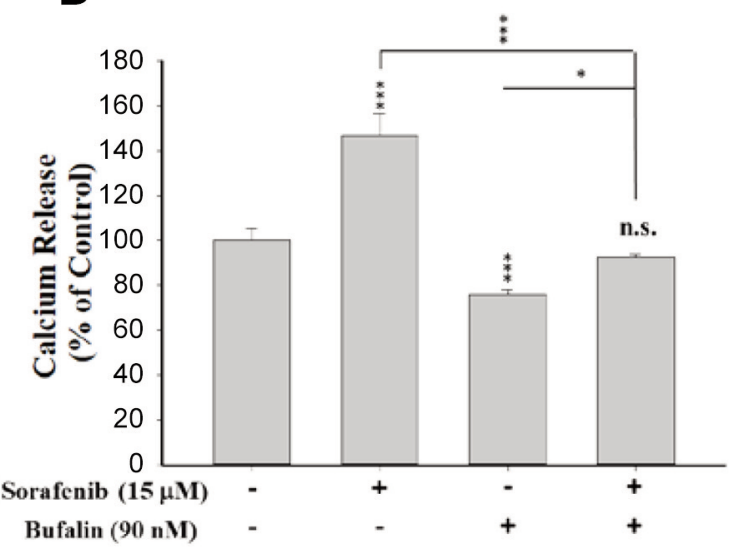

$\mathbf{F}$

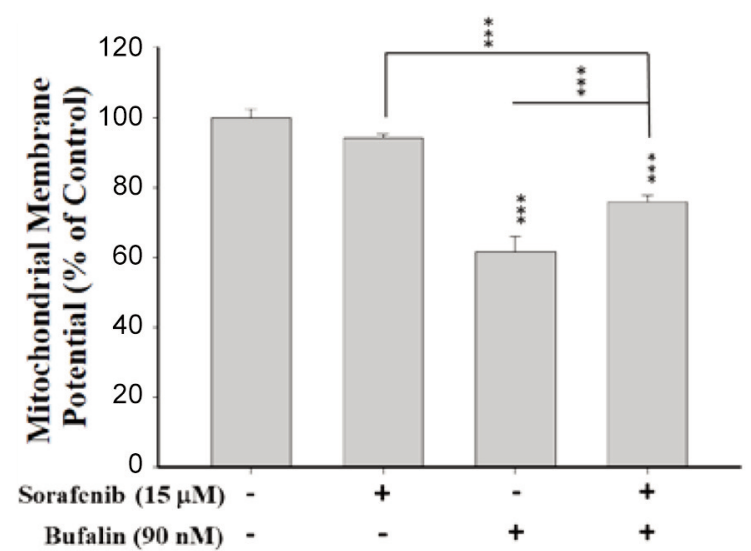

Figure 4. The effects of sorafenib, bufalin, or the combination of sorafenib with bufalin on the production of reactive oxygen species (ROS) and Ca ${ }^{2+}$ and the levels of mitochondrial membrane potential $(\Delta \Psi \mathrm{m})$ in NCI-H292 cells. Cells $\left(1 \times 10^{5}\right.$ cells/well) were treated $15 \mu \mathrm{M}$ sorafenib, $90 \mathrm{nM}$ bufalin, or the combination of $15 \mu \mathrm{M}$ sorafenib with $90 \mathrm{nM}$ bufalin for $48 \mathrm{~h}$. Then cells were collected and resuspended in DCFH-DA solution for measuring the changes of $\mathrm{ROS}\left(\mathrm{H}_{2} \mathrm{O}_{2}\right)(\mathrm{A}$ and $\mathrm{B})$, in Fluo-3/AM solution for measuring intracellular $\mathrm{Ca}^{2+}$ level $(\mathrm{C}$ and $\mathrm{D})$, and in DiOC 6 reagent for measuring $\Delta \Psi_{m}$ levels $(E$ and $F)$ by flow cytometry. Data represent mean $\pm S D$. ${ }^{*} p<0.05$, $* * p<0.01$, or ${ }^{* * *} p<0.001$, a significant difference when compared to sorafenib- or bufalin-treated alone. n.s., No significant difference when compared to sorafenib- or bufalin-treated alone ( $p>0.05)$. 
A

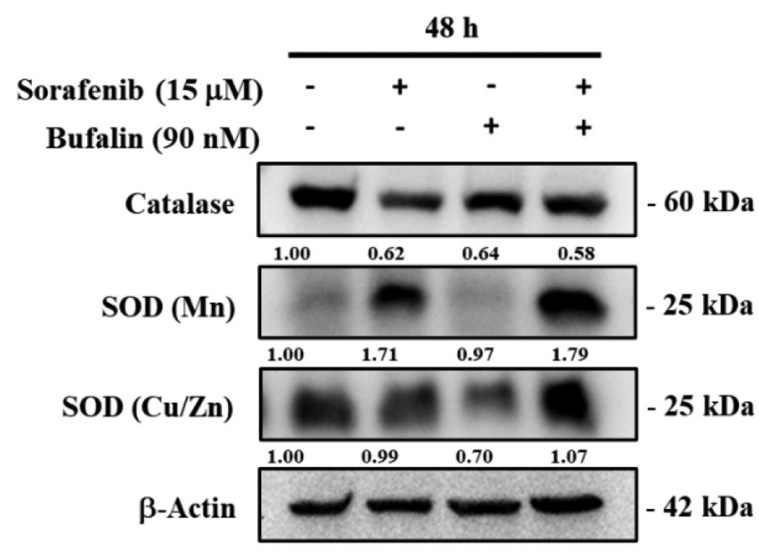

C

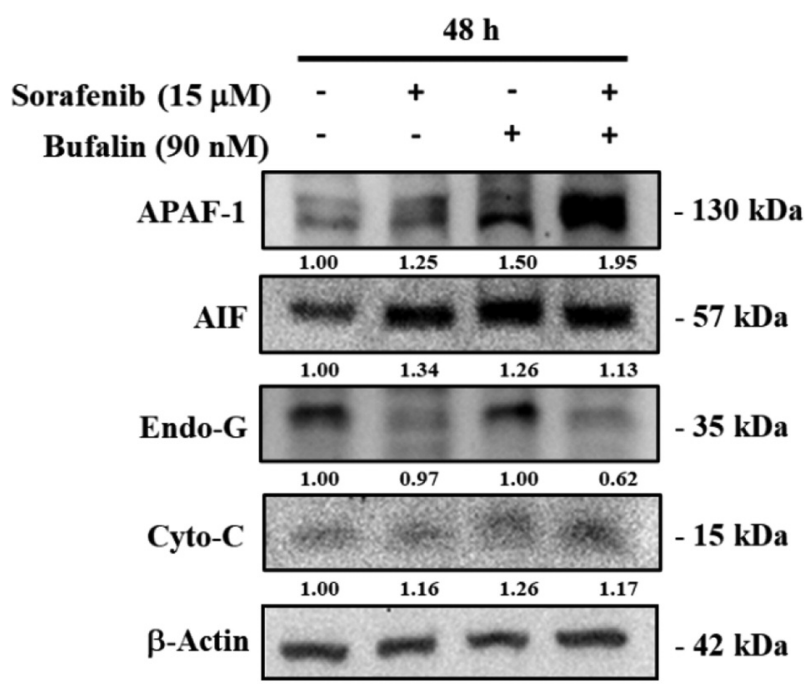

B

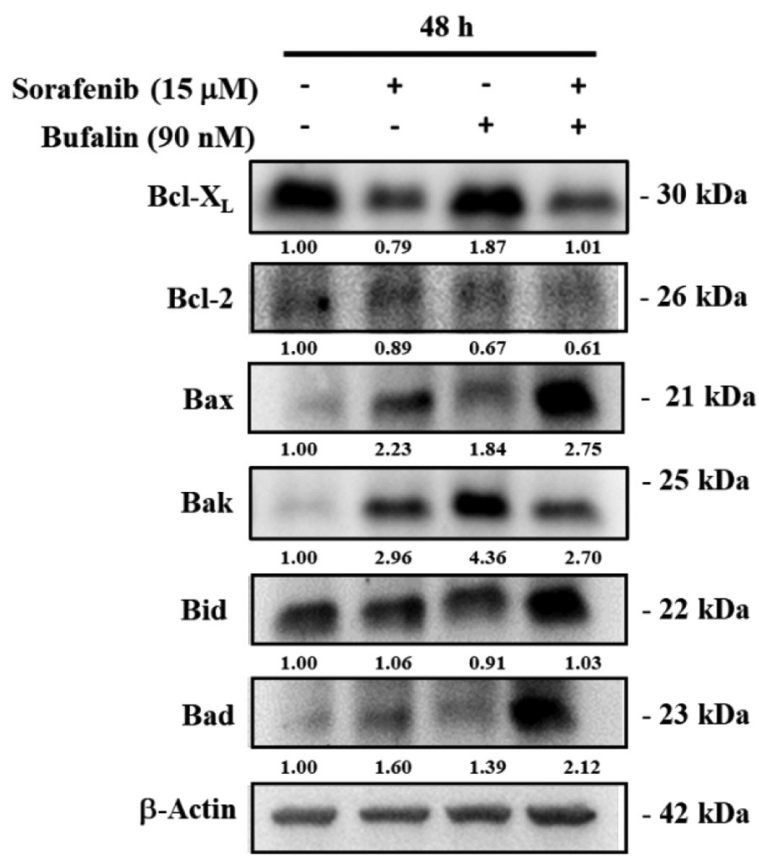

D

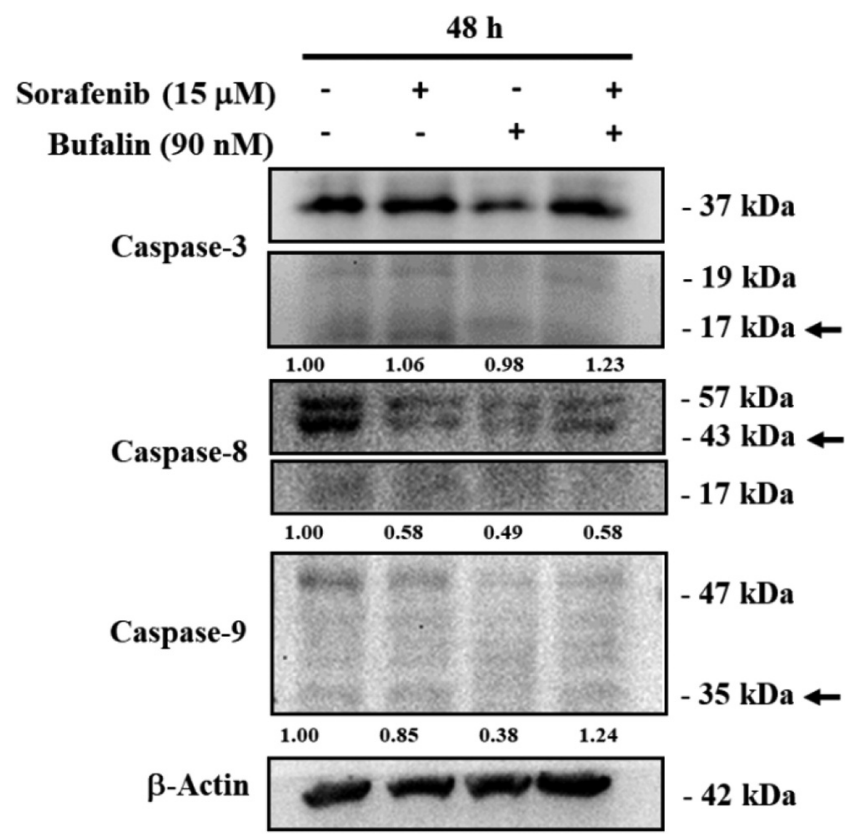

Figure 5. The effects of sorafenib, bufalin, or the combination of sorafenib with bufalin on the ROS- or apoptosis-associated proteins in NCI-H292 cells. Cells $\left(1 \times 10^{6}\right.$ cells/well $)$ were subjected to $15 \mu \mathrm{M}$ sorafenib, $90 \mathrm{nM}$ bufalin, or the combination of $15 \mu \mathrm{M}$ sorafenib with $90 \mathrm{nM}$ bufalin for $48 \mathrm{~h}$. Cells were collected and lysed, and their total proteins were quantified and analyzed by western blotting. The blotting was probed with primary antibodies against anti-SOD (Mn), -SOD (Cu/Zn), and -catalase (A); -Bcl-X $,-B c l-2,-B a x,-B a k,-B i d$, and -Bad (B); -APAF-1, -AIF, -Endo G, and -Cytochrome $C(C)$; -caspase-3, -caspase-8, and -caspase- $8(D)$. Then the membranes were washed, followed by incubation with responding secondary antibody (anti-mouse or anti-rabbit antibodies). The protein signals were detected by ECL and quantified by the ImageJ software. 
(36). Besides, a synergistic inhibitory effect of the sorafenib and gemcitabine combination treatment on NSCLC cells has been found in vitro and in vivo (37). Another study has shown that the combination therapy increases cytotoxic efficiency in lung cancer cells with EGFR-TKI-resistance (38). Based on the findings of this study, we offer novel information regarding the efficacy of sorafenib in combination with bufalin for lung cancer therapy.

In order to confirm the involvement of apoptosis and DNA condensation in mediating reduced cell viability in NCI-H292 cells upon treatment with sorafenib in combination with bufalin, two different assays, including Annexin V-FITC/PI and DAPI staining, were performed, respectively. The results indicated that combination treatment demonstrates higher apoptotic cell death (Figure 2A and B) and DNA condensation (Figure $3 \mathrm{~A}$ and $\mathrm{B}$ ) than that upon treatment with sorafenib or bufalin only for $48 \mathrm{~h}$. These observations suggest that the two-drug combination of sorafenib and bufalin has a synergistic effect on induction of apoptotic cell death and reduction of cell viability in NCIH292 cells. However, the conceivable signaling pathways involved in the two-drug combination treatment warrant further investigation.

To further confirm the involvement of ROS-mediated pathways in the combination treatment-induced cell death, we analyzed the ROS production in NCI-H292 cells. Our results suggest that the effect of sorafenib on ROS production is different from that of bufalin. Sorafenib increased the levels of ROS, but bufalin decreased it. The combination treatment leads to lower production of ROS compared to that with sorafenib treatment alone. In contrast, the ROS levels were found to be higher in cells subjected to the combined treatment as compared to treatment with bufalin alone (Figure 4A and B). ROS is well-known for its involvement in metabolic processes (39). Low-level ROS is essential for maintaining cellular signaling. However, it may play different roles, especially in pathophysiological conditions, including cancer cells (40). High-level production of ROS can trigger oxidative stress and result in cell component damage and apoptosis (40). Considerable evidence has shown that certain anti-cancer drugs inducedcell death is associated with high ROS production and $\mathrm{Ca}^{2+}$ release $(41,42)$.

It is well-established that ROS production leads to mitochondrial dysregulation. Our data show that sorafenib revealed no effect on the permeability of mitochondria, but bufalin significantly decreased the level of mitochondrial membrane potential in NCI-H292 cells. The two-drug combination treatment of NCI-H292 cells results in not only a lower ROS production (Figure 4A and B) but also lowers mitochondrial membrane potential levels $(\Delta \Psi m)$ (Figure 4E and F) as compared to the treatment with sorafenib alone. However, the same treatment results in a higher ROS production and mitochondrial membrane potential than that upon bufalin treatment alone. Further investigation was performed for understanding the molecular mechanism underlying the higher apoptotic cell death upon the combination treatment of NCI-H292 cells than upon sorafenib or bufalin treatment only. Western blotting results revealed that combined treatment significantly triggered ROS responses, including elevated SOD $(\mathrm{Mn})$ and SOD $(\mathrm{Cu} / \mathrm{Zn})$, but decreased catalase levels as compared to that upon sorafenib or bufalin treatment alone (Figure 5A). Overall, these observations offer a further detailed understanding of the molecular mechanism underlying higher apoptotic cell death upon treatment with the combination of sorafenib and bufalin as compared to that of sorafenib or bufalin treatment alone.

Furthermore, the capability of targeting mitochondriarelated components indicates the therapeutic potential of a drug combination. Accordingly, the drugs that can inhibit the levels of Bcl-2 and Bcl- $\mathrm{X}_{\mathrm{L}}$, and increase the release of AIF, cytochrome $c$, and APAF-1, ultimately trigger cells to undergo apoptosis. Our data show that the two-drug treatment significantly reduced the levels of $\Delta \Psi \mathrm{m}$ as compared to sorafenib treatment alone (Figure $4 \mathrm{E}$ and F). The $\Delta \Psi m$ plays a critical role in the release of cytochrome c and apoptosome assembling $(43,44)$. Furthermore, we have found that the two-drug combination exerts more efficient apoptosis-inducing effects through the mitochondrial-dependent pathway at the translational level. Our results revealed that the two-drug combination shows the lower expression of Bcl-2 (anti-apoptotic protein) and higher levels of Bax and Bad (pro-apoptotic proteins) in NCI-H292 cells as compared to sorafenib or bufalin treatment alone (Figure 5B). Once activated, both Bak and Bax oligomerize on the outer mitochondrial membrane to drive its rupture and then result in the initiation of the intrinsic apoptosis pathway in the mitochondrial compartment (45). Furthermore, the combination treatment also resulted in higher cytochrome c and APAF-1 levels in addition to the active form of caspase- 3 and -9 than that upon treatment with sorafenib or bufalin alone (Figure 5C and D). The Bcl-2 family of proteins, functioning as both pro- and anti-apoptotic components, have been recognized as a group of upstream regulators of the caspase cascade $(46,47)$. Bcl-2 and Bcl- $\mathrm{X}_{\mathrm{L}}$ prevent cell death by blocking the activation of caspases (48). In the normal condition, both $\mathrm{Bcl}-2$ and $\mathrm{Bcl}-\mathrm{X}_{\mathrm{L}}$ are limited in the mitochondria to avoid the release of cytochrome $c$ (49) and AIF (apoptosisinducing factor) (50) from the inter-membrane space of mitochondria into the cytoplasm. Their antiapoptotic activity has been modulated through proteolytic cleavage by caspases $(51,52)$. Tiam 1 is overexpressed or mutated in epithelial cancers with poor prognosis, including nonsmall cell lung cancer (53). Tiam1 is related to the 


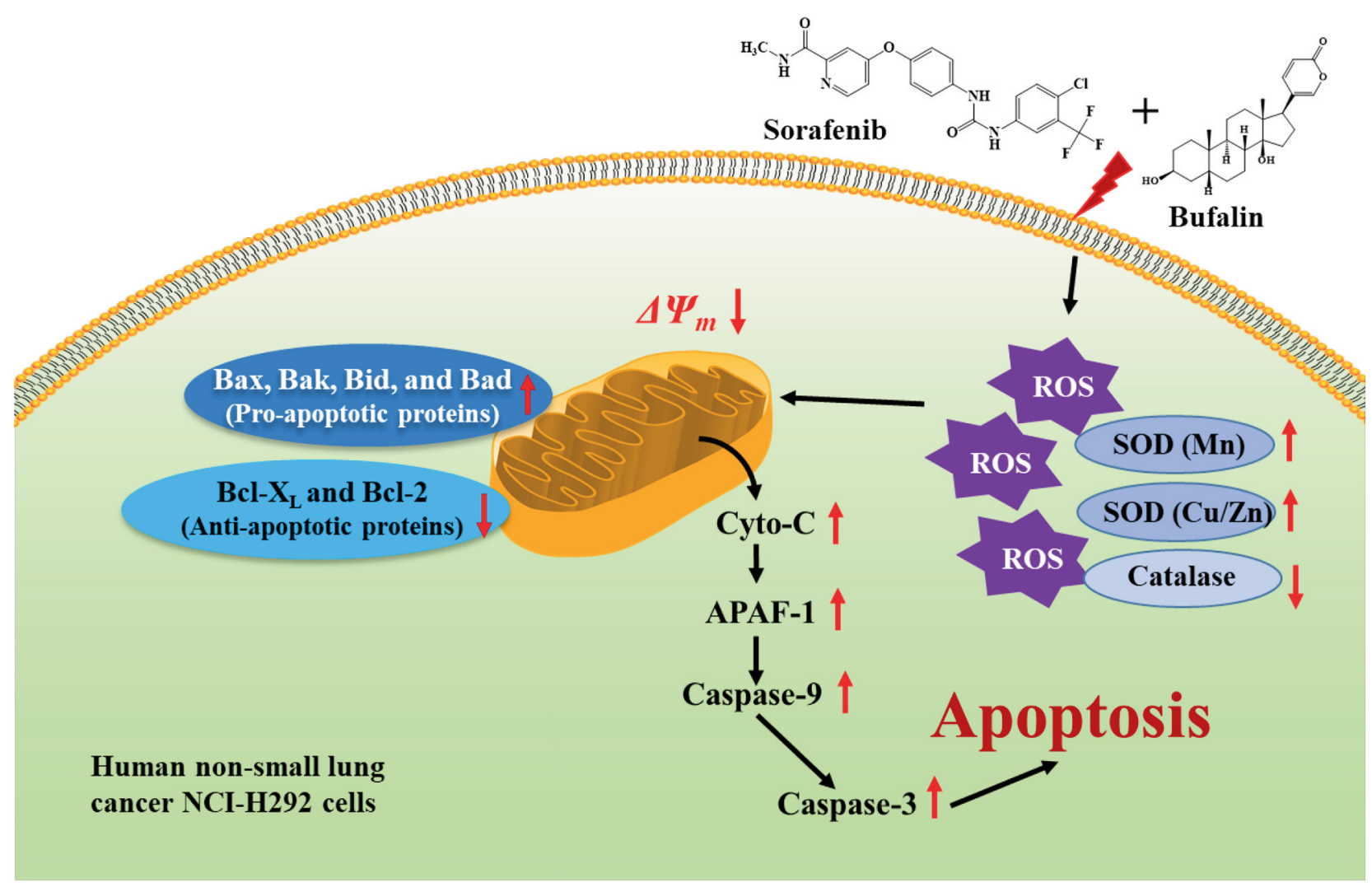

Figure 6. The possible molecular mechanisms of combination of sorafenib with bufalin induced cell apoptosis in NCI-H292 cells in vitro.

downstream mediator of bufalin-induced apoptosis in the human HeLa and leukemia cell lines (54). The involvement of Tiam 1 in the treatment of bufalin combined with sorafenib needs to be clarified in the future.

Sorafenib combined with bufalin may provide a novel pathway for the therapy of NSCLC. Sorafenib targeted Raf kinase in the Raf/MEK/ERK pathway, and it inhibited tumor growth in xenograft models (55). Bufalin induced apoptosis through several signaling pathways in NSCLC cells. Bufalin induced apoptosis by degradation of Mcl-1 through GSK-3 $\beta$ activation in NSCLC H1975 Cells (56). In addition, it also induced apoptosis through ROS-, mitochondrial, and DNA damage and repair-associated pathways $(25,57,58)$. However, sorafenib induced both PI3K- and oxidative stressrelated pathways that enhanced apoptotic effects in NSCLC and glioma cells, respectively $(59,60)$. Hence, in this study, sorafenib combined with bufalin enhanced the apoptosis effects may mediate the targets of Raf kinase and ROS-, mitochondrial-, or DNA damage and repair-associated pathways. The detailed mechanism need to be clarified in the future.

In conclusion, the present study showed that sorafenib in combination with bufalin demonstrates greater cytotoxic effects and results in enhanced chromatin condensation and cell apoptosis (apoptotic cell death) compred to sorafenib or bufalin treatment only in NCI-H292 cells in vitro. In addition, this combined treatment triggered higher ROS production and lower mitochondrial membrane potential than that of sorafenib treatment only. Furthermore, the likely signaling pathways activated upon combined treatment-induced apoptosis in NCI-H292 cells in vitro may be mediated with ROS-, mitochondria-, and caspaseassociated signaling pathways that are summarized in Figure 6.

\section{Conflicts of Interest}

The Authors declare that they have no conflicts of interest regarding the present study.

\section{Authors' Contributions}

Study conception and design: JYK, SFP and JGC; Acquisition of data: JYK, CLL, YSM, and CLK; Analysis and interpretation of data: JYK, JCC, YPH, and WWH; Drafting of manuscript: SFP and JGC; Critical revision: SFP and JGC. All Authors discussed the results and commented on the article. 


\section{Acknowledgements}

The present study was supported by Grants CMU109-ASIA-16 (China Medical University, Taichung, Taiwan, R.O.C.) and DMR105-095 (China Medical University Hospital, Taichung, Taiwan, R.O.C.). Experiments and data analysis were performed in part through the use of the Medical Research Core Facilities Center, Office of Research \& Development at China Medical University, Taichung, Taiwan, R.O.C.

\section{References}

1 Ferlay J, Soerjomataram I, Dikshit R, Eser S, Mathers C, Rebelo M, Parkin DM, Forman D and Bray F: Cancer incidence and mortality worldwide: sources, methods and major patterns in GLOBOCAN 2012. Int J Cancer 136(5): E359-E386, 2015. PMID: 25220842. DOI: 10.1002/ijc.29210

2 Jemal A, Thun MJ, Ries LA, Howe HL, Weir HK, Center MM, Ward E, Wu XC, Eheman C, Anderson R, Ajani UA, Kohler B and Edwards BK: Annual report to the nation on the status of cancer, 1975-2005, featuring trends in lung cancer, tobacco use, and tobacco control. J Natl Cancer Inst 100(23): 16721694, 2008. PMID: 19033571. DOI: 10.1093/jnci/djn389

3 Valdes M, Nicholas G, Goss GD and Wheatley-Price P: Chemotherapy in recurrent advanced non-small-cell lung cancer after adjuvant chemotherapy. Curr Oncol 23(6): 386-390, 2016. PMID: 28050134. DOI: $10.3747 /$ co.23.3191

4 Lung Cancer Survival Rates. The American Cancer Society medical and editorial content team. Available at: http:// www.cancer.org/cancer/lung-cancer/detection-diagnosis-staging/ survival-rates.html [Last accessed on January 29, 2021]

5 Dholaria B, Hammond W, Shreders A and Lou Y: Emerging therapeutic agents for lung cancer. J Hematol Oncol 9(1): 138, 2016. PMID: 27938382. DOI: 10.1186/s13045-016-0365-z

6 Zhang J, Gold KA and Kim E: Sorafenib in non-small cell lung cancer. Expert Opin Investig Drugs 21(9): 1417-1426, 2012. PMID: 22725255. DOI: 10.1517/13543784.2012.699039

7 Blumenschein GR Jr, Gatzemeier U, Fossella F, Stewart DJ, Cupit L, Cihon F, O'Leary J and Reck M: Phase II, multicenter, uncontrolled trial of single-agent sorafenib in patients with relapsed or refractory, advanced non-small-cell lung cancer. J Clin Oncol 27(26): 4274-4280, 2009. PMID: 19652055. DOI: 10.1200/JCO.2009.22.0541

8 Imielinski M, Greulich H, Kaplan B, Araujo L, Amann J, Horn L, Schiller J, Villalona-Calero MA, Meyerson M and Carbone DP: Oncogenic and sorafenib-sensitive ARAF mutations in lung adenocarcinoma. J Clin Invest 124(4): 1582-1586, 2014. PMID: 24569458. DOI: $10.1172 / J C I 72763$

9 Zhang J, Chen YL, Ji G, Fang W, Gao Z, Liu Y, Wang J, Ding $X$ and Gao F: Sorafenib inhibits epithelial-mesenchymal transition through an epigenetic-based mechanism in human lung epithelial cells. PLoS One 8(5): e64954, 2013. PMID: 23741434. DOI: $10.1371 /$ journal.pone.0064954

10 Gadaleta-Caldarola G, Divella R, Mazzocca A, Infusino S, Ferraro E, Filippelli G, Daniele A, Sabbà C, Abbate I and Brandi M: Sorafenib: the gold standard therapy in advanced hepatocellular carcinoma and beyond. Future Oncol 11(16): 2263-2266, 2015. PMID: 26260805. DOI: 10.2217/fon.15.161

11 Takezawa K, Okamoto I, Yonesaka K, Hatashita E, Yamada Y, Fukuoka M and Nakagawa K: Sorafenib inhibits non-small cell lung cancer cell growth by targeting B-RAF in KRAS wild-type cells and C-RAF in KRAS mutant cells. Cancer Res 69(16): 6515-6521, 2009. PMID: 19638574. DOI: 10.1158/00085472.CAN-09-1076

12 Ngamphaiboon N, Dy GK, Ma WW, Zhao Y, Reungwetwattana T, DePaolo D, Ding Y, Brady W, Fetterly G and Adjei AA: A phase I study of the histone deacetylase (HDAC) inhibitor entinostat, in combination with sorafenib in patients with advanced solid tumors. Invest New Drugs 33(1): 225-232, 2015. PMID: 25371323. DOI: 10.1007/s10637-014-0174-6

13 Jean GW, Mani RM, Jaffry A and Khan SA: Toxic effects of sorafenib in patients with differentiated thyroid carcinoma compared with other cancers. JAMA Oncol 2(4): 529-534, 2016. PMID: 26847808. DOI: 10.1001/jamaoncol.2015.5927

14 Robles-Fernández I, Rodríguez-Serrano F, Álvarez PJ, Ortiz R, Rama AR, Prados J, Melguizo C, Álvarez-Manzaneda E and Aránega A: Antitumor properties of natural compounds and related molecules. Recent Pat Anticancer Drug Discov 8(3): 203-215, 2013. PMID: 23157341. DOI: 10.2174/1574891x113089990034

15 Krenn L and Kopp B: Bufadienolides from animal and plant sources. Phytochemistry 48(1): 1-29, 1998. PMID: 9621450. DOI: 10.1016/s0031-9422(97)00426-3

16 Panesar NS: Bufalin and unidentified substance(s) in traditional Chinese medicine cross-react in commercial digoxin assay. Clin Chem 38(10): 2155-2156, 1992. PMID: 1395015.

17 Watabe M, Ito K, Masuda Y, Nakajo S and Nakaya K: Activation of AP-1 is required for bufalin-induced apoptosis in human leukemia U937 cells. Oncogene 16(6): 779-787, 1998. PMID: 9488042. DOI: 10.1038/sj.onc.1201592

18 Huang WW, Yang JS, Pai SJ, Wu PP, Chang SJ, Chueh FS, Fan MJ, Chiou SM, Kuo HM, Yeh CC, Chen PY, Tsuzuki M and Chung JG: Bufalin induces G0/G1 phase arrest through inhibiting the levels of cyclin D, cyclin E, CDK2 and CDK4, and triggers apoptosis via mitochondrial signaling pathway in T24 human bladder cancer cells. Mutat Res 732(1-2): 26-33, 2012. PMID: 22285700. DOI: 10.1016/j.mrfmmm.2011.09.010

19 Li D, Qu X, Hou K, Zhang Y, Dong Q, Teng Y, Zhang J and Liu $\mathrm{Y}$ : PI3K/Akt is involved in bufalin-induced apoptosis in gastric cancer cells. Anticancer Drugs 20(1): 59-64, 2009. PMID: 19343001. DOI: 10.1097/CAD.0b013e3283160fd6

$20 \mathrm{Yu}$ CH, Kan SF, Pu HF, Jea Chien E and Wang PS: Apoptotic signaling in bufalin- and cinobufagin-treated androgendependent and -independent human prostate cancer cells. Cancer Sci 99(12): 2467-2476, 2008. PMID: 19037992. DOI: 10.1111/ j.1349-7006.2008.00966.X

21 Shen S, Zhang Y, Wang Z, Liu R and Gong X: Bufalin induces the interplay between apoptosis and autophagy in glioma cells through endoplasmic reticulum stress. Int J Biol Sci 10(2): 212224, 2014. PMID: 24550689. DOI: 10.7150/ijbs.8056

22 Li Y, Tian X, Liu X and Gong P: Bufalin inhibits human breast cancer tumorigenesis by inducing cell death through the ROSmediated RIP1/RIP3/PARP-1 pathways. Carcinogenesis 39(5): 700-707, 2018. PMID: 29546393. DOI: 10.1093/carcin/bgy039

23 Qi F, Inagaki Y, Gao B, Cui X, Xu H, Kokudo N, Li A and Tang W: Bufalin and cinobufagin induce apoptosis of human hepatocellular carcinoma cells via Fas- and mitochondriamediated pathways. Cancer Sci 102(5): 951-958, 2011. PMID: 21288283. DOI: 10.1111/j.1349-7006.2011.01900.x

24 Su EY, Chu YL, Chueh FS, Ma YS, Peng SF, Huang WW, Liao $\mathrm{CL}$, Huang AC and Chung JG: Bufalin induces apoptotic cell 
death in human nasopharyngeal carcinoma cells through mitochondrial ROS and TRAIL pathways. Am J Chin Med 47(1): 237-257, 2019. PMID: 30612454. DOI: 10.1142/ S0192415X19500125

25 Wu SH, Bau DT, Hsiao YT, Lu KW, Hsia TC, Lien JC, Ko YC, Hsu WH, Yang ST, Huang YP and Chung JG: Bufalin induces apoptosis in vitro and has Antitumor activity against human lung cancer xenografts in vivo. Environ Toxicol 32(4): 1305-1317, 2017. PMID: 27444971. DOI: 10.1002/tox.22325

26 Shih YL, Chou JS, Chen YL, Hsueh SC, Chung HY, Lee MH, Chen CP, Lee MZ, Hou HT, Lu HF, Chen KW and Chung JG: Bufalin enhances immune responses in leukemic mice through enhancing phagocytosis of macrophage in vivo. In Vivo 32(5): 1129-1136, 2018. PMID: 30150435. DOI: 10.21873/invivo. 11355

27 Chen CJ, Shih YL, Yeh MY, Liao NC, Chung HY, Liu KL, Lee MH, Chou PY, Hou HY, Chou JS and Chung JG: Ursolic acid induces apoptotic cell death through AIF and Endo G release through a mitochondria-dependent pathway in NCI-H292 human lung cancer cells in vitro. In Vivo 33(2): 383-391, 2019. PMID: 30804116. DOI: 10.21873 /invivo. 11485

28 Hsiao YT, Kuo CL, Lin JJ, Huang WW, Peng SF, Chueh FS, Bau DT and Chung JG: Curcuminoids combined with gefitinib mediated apoptosis and autophagy of human oral cancer SAS cells in vitro and reduced tumor of SAS cell xenograft mice in vivo. Environ Toxicol, 2018. PMID: 29717538. DOI: 10.1002/ tox. 22568

29 Scagliotti GV, De Marinis F, Rinaldi M, Crinò L, Gridelli C, Ricci S, Matano E, Boni C, Marangolo M, Failla G, Altavilla G, Adamo V, Ceribelli A, Clerici M, Di Costanzo F, Frontini L, Tonato $\mathrm{M}$ and Italian Lung Cancer Project: Phase III randomized trial comparing three platinum-based doublets in advanced nonsmall-cell lung cancer. J Clin Oncol 20(21): 4285-4291, 2002. PMID: 12409326. DOI: 10.1200/JCO.2002.02.068

30 Scagliotti G, Novello S, von Pawel J, Reck M, Pereira JR, Thomas M, Abrão Miziara JE, Balint B, De Marinis F, Keller A, Arén O, Csollak M, Albert I, Barrios CH, Grossi F, Krzakowski M, Cupit L, Cihon F, Dimatteo S and Hanna N: Phase III study of carboplatin and paclitaxel alone or with sorafenib in advanced non-small-cell lung cancer. J Clin Oncol 28(11): 1835-1842, 2010. PMID: 20212250. DOI: 10.1200/JCO.2009.26.1321

31 Paz-Ares L, Hirsh V, Zhang L, de Marinis F, Yang JC, Wakelee HA, Seto T, Wu YL, Novello S, Juhász E, Arén O, Sun Y, Schmelter T, Ong TJ, Peña C, Smit EF and Mok TS: Monotherapy administration of sorafenib in patients with nonsmall cell lung cancer (MISSION) trial: A phase III, multicenter, placebo-controlled trial of sorafenib in patients with relapsed or refractory predominantly nonsquamous non-small-cell lung cancer after 2 or 3 previous treatment regimens. J Thorac Oncol 10(12): 1745-1753, 2015. PMID: 26743856. DOI: 10.1097/JTO 0000000000000693

32 Kang XH, Xu ZY, Gong YB, Wang LF, Wang ZQ, Xu L, Cao F and Liao MJ: Bufalin reverses HGF-induced resistance to EGFR-TKIs in EGFR mutant lung cancer cells via blockage of Met/PI3k/Akt pathway and induction of apoptosis. Evid Based Complement Alternat Med 2013: 243859, 2013. PMID: 23533466. DOI: 10.1155/2013/243859

33 Hsiao YP, Yu CS, Yu CC, Yang JS, Chiang JH, Lu CC, Huang HY, Tang NY, Yang JH, Huang AC and Chung JG: Triggering apoptotic death of human malignant melanoma a375.s2 cells by bufalin: involvement of caspase cascade-dependent and independent mitochondrial signaling pathways. Evid Based Complement Alternat Med 2012: 591241, 2012. PMID: 22719785. DOI: 10.1155/2012/591241

34 Yan S, Qu X, Xu C, Zhu Z, Zhang L, Xu L, Song N, Teng Y and Liu Y: Down-regulation of Cbl-b by bufalin results in up-regulation of DR4/DR5 and sensitization of TRAIL-induced apoptosis in breast cancer cells. J Cancer Res Clin Oncol 138(8): 1279-1289, 2012. PMID: 22447040. DOI: 10.1007/s00432-012-1204-4

35 Tsai SC, Yang JS, Peng SF, Lu CC, Chiang JH, Chung JG, Lin MW, Lin JK, Amagaya S, Wai-Shan Chung C, Tung TT, Huang WW and Tseng MT: Bufalin increases sensitivity to AKT/mTOR-induced autophagic cell death in SK-HEP-1 human hepatocellular carcinoma cells. Int J Oncol 41(4): 1431-1442, 2012. PMID: 22858649. DOI: 10.3892/ijo.2012.1579

36 Kutkowska J, Strzadala L and Rapak A: Synergistic activity of sorafenib and betulinic acid against clonogenic activity of nonsmall cell lung cancer cells. Cancer Sci 108(11): 2265-2272, 2017. PMID: 28846180. DOI: $10.1111 /$ cas.13386

37 Jiang S, Wang R, Zhang X, Wu F, Li S and Yuan Y: Combination treatment of gemcitabine and sorafenib exerts a synergistic inhibitory effect on non-small cell lung cancer in vitro and in vivo via the epithelial-to-mesenchymal transition process. Oncol Lett 20(1): 346-356, 2020. PMID: 32537024. DOI: $10.3892 / \mathrm{ol} .2020 .11536$

38 Li J, Pan YY and Zhang Y: Sorafenib combined with gemcitabine in EGFR-TKI-resistant human lung cancer cells. Oncol Lett 5(1): 68-72, 2013. PMID: 23255896. DOI: 10.3892/ol.2012.958

39 Zhang J, Wang X, Vikash V, Ye Q, Wu D, Liu Y and Dong W: ROS and ROS-mediated cellular signaling. Oxid Med Cell Longev 2016: 4350965, 2016. PMID: 26998193. DOI: $10.1155 / 2016 / 4350965$

40 Galadari S, Rahman A, Pallichankandy S and Thayyullathil F: Reactive oxygen species and cancer paradox: To promote or to suppress? Free Radic Biol Med 104: 144-164, 2017. PMID: 28088622. DOI: 10.1016/j.freeradbiomed.2017.01.004

41 Shang HS, Shih YL, Lu TJ, Lee CH, Hsueh SC, Chou YC, Lu HF, Liao NC and Chung JG: Benzyl isothiocyanate (BITC) induces apoptosis of GBM 8401 human brain glioblastoma multiforms cells via activation of caspase-8/Bid and the reactive oxygen species-dependent mitochondrial pathway. Environ Toxicol 31(12): 1751-1760, 2016. PMID: 28675694. DOI: 10.1002/tox.22177

42 Shang HS, Liu JY, Lu HF, Chiang HS, Lin CH, Chen A, Lin YF and Chung JG: Casticin induced apoptotic cell death and altered associated gene expression in human colon cancer colo 205 cells. Environ Toxicol 32(8): 2041-2052, 2017. PMID: 27862857. DOI: $10.1002 /$ tox.22381

43 Ow YP, Green DR, Hao Z and Mak TW: Cytochrome c: functions beyond respiration. Nat Rev Mol Cell Biol 9(7): 532542, 2008. PMID: 18568041. DOI: $10.1038 / \mathrm{nrm} 2434$

44 Tait SW and Green DR: Mitochondria and cell death: outer membrane permeabilization and beyond. Nat Rev Mol Cell Biol 11(9): 621-632, 2010. PMID: 20683470. DOI: 10.1038/nrm 2952

45 Chota A, George BP and Abrahamse $\mathrm{H}$ : Interactions of multidomain pro-apoptotic and anti-apoptotic proteins in cancer cell death. Oncotarget 12(16): 1615-1626, 2021. PMID: 34381566. DOI: $10.18632 /$ oncotarget.28031

46 Danial NN and Korsmeyer SJ: Cell death: critical control points. Cell 116(2): 205-219, 2004. PMID: 14744432. DOI: 10.1016/ s0092-8674(04)00046-7 
47 Youle RJ and Strasser A: The BCL-2 protein family: opposing activities that mediate cell death. Nat Rev Mol Cell Biol 9(1): 47-59, 2008. PMID: 18097445. DOI: $10.1038 / \mathrm{nrm} 2308$

48 Yasuhara N, Sahara S, Kamada S, Eguchi Y and Tsujimoto Y: Evidence against a functional site for Bcl-2 downstream of caspase cascade in preventing apoptosis. Oncogene 15(16): 1921-1928, 1997. PMID: 9365238. DOI: 10.1038/sj.onc. 1201370

49 Kluck RM, Bossy-Wetzel E, Green DR and Newmeyer DD: The release of cytochrome $\mathrm{c}$ from mitochondria: a primary site for Bcl-2 regulation of apoptosis. Science 275(5303): 1132-1136, 1997. PMID: 9027315. DOI: 10.1126/science.275.5303.1132

50 Susin SA, Zamzami N, Castedo M, Hirsch T, Marchetti P, Macho A, Daugas E, Geuskens M and Kroemer G: Bcl-2 inhibits the mitochondrial release of an apoptogenic protease. J Exp Med 184(4): 1331-1341, 1996. PMID: 8879205. DOI: 10.1084/jem. 184.4.1331

51 Cheng EH, Kirsch DG, Clem RJ, Ravi R, Kastan MB, Bedi A, Ueno K and Hardwick JM: Conversion of Bcl-2 to a Bax-like death effector by caspases. Science 278(5345): 1966-1968, 1997. PMID: 9395403. DOI: 10.1126/science.278.5345.1966

52 Clem RJ, Cheng EH, Karp CL, Kirsch DG, Ueno K, Takahashi A, Kastan MB, Griffin DE, Earnshaw WC, Veliuona MA and Hardwick JM: Modulation of cell death by Bcl-XL through caspase interaction. Proc Natl Acad Sci U.S.A. 95(2): 554-559, 1998. PMID: 9435230. DOI: 10.1073/pnas.95.2.554

53 Maldonado MDM, Medina JI, Velazquez L and Dharmawardhane S: Targeting Rac and Cdc42 GEFs in metastatic cancer. Front Cell Dev Biol 8: 201, 2020. PMID: 32322580. DOI: $10.3389 /$ fcell.2020.00201

54 Cao-Hong, Shibayama-Imazu T, Masuda Y, Shinki T, Nakajo S and Nakaya K: Involvement of Tiam 1 in apoptosis induced by bufalin in HeLa cells. Anticancer Res 27(1A): 245-249, 2007. PMID: 17352239.

55 Wilhelm S, Carter C, Lynch M, Lowinger T, Dumas J, Smith RA, Schwartz B, Simantov R and Kelley S: Discovery and development of sorafenib: a multikinase inhibitor for treating cancer. Nat Rev Drug Discov 5(10): 835-844, 2006. PMID: 17016424. DOI: $10.1038 / \mathrm{nrd} 2130$
56 Kang XH, Zhang JH, Zhang QQ, Cui YH, Wang Y, Kou WZ, Miao ZH, Lu P, Wang LF, Xu ZY and Cao F: Degradation of Mcl-1 through GSK-3 $\beta$ activation regulates apoptosis induced by bufalin in non-small cell lung cancer H1975 cells. Cell Physiol Biochem 41(5): 2067-2076, 2017. PMID: 28419994. DOI: $10.1159 / 000475438$

57 Wu SH, Wu TY, Hsiao YT, Lin JH, Hsu SC, Hsia TC, Yang ST, Hsu WH and Chung JG: Bufalin induces cell death in human lung cancer cells through disruption of DNA damage response pathways. Am J Chin Med 42(3): 729-742, 2014. PMID: 24871662. DOI: 10.1142/S0192415X14500475

58 Ding DW, Zhang YH, Huang XE, An Q and Zhang X: Bufalin induces mitochondrial pathway-mediated apoptosis in lung adenocarcinoma cells. Asian Pac J Cancer Prev 15(23): 1049510500, 2014. PMID: 25556498. DOI: 10.7314/apjcp. 2014.15.23.10495

59 Wang J, Ma S, Chen X, Zhang S, Wang Z and Mei Q: The novel PI3K inhibitor $\mathrm{S} 1$ synergizes with sorafenib in non-small cell lung cancer cells involving the Akt-S6 signaling. Invest New Drugs 37(5): 828-836, 2019. PMID: 30456603. DOI: 10.1007/ s10637-018-0698-2

60 Wei J, Wang Z, Wang W, Liu X, Wan J, Yuan Y, Li X, Ma L and Liu X: Oxidative stress activated by sorafenib alters the temozolomide sensitivity of human glioma cells through autophagy and JAK2/STAT3-AIF axis. Front Cell Dev Biol 9: 660005, 2021. PMID: 34277607. DOI: 10.3389/fcell.2021.660005

Received October 6, 2021

Revised December 3, 2021 Accepted December 13, 2021 